\title{
The human $\beta$-globin locus control region confers an early embryonic erythroid-specific expression pattern to a basic promoter driving the bacterial
}

\section{lacZ gene}

\author{
Rita Tewari ${ }^{1}$, Nynke Gillemans ${ }^{1}$, Alex Harper², Mark Wijgerde', Gaetano Zafarana ${ }^{1}$, Dubravka Drabek ${ }^{1}$, \\ Frank Grosveld ${ }^{1, *}$ and Sjaak Philipsen ${ }^{1}$ \\ ${ }^{1}$ Erasmus University Rotterdam, Department of Cell Biology, P.O. Box 1738, 3000 DR Rotterdam, The Netherlands \\ 2Transgenic Research Institute, The Rayne Institute, St Thomas' Hospital, London SE1 7EH, UK \\ *Author for correspondence (e-mail: vanderkamp@ch1.fgg.eur.nl)
}

\section{SUMMARY}

The $\beta$-globin locus control region $(\mathrm{LCR})$ is contained on a $20 \mathrm{~kb}$ DNA fragment and is characterized by the presence of five DNaseI hypersensitive sites in erythroid cells, termed $5^{\prime} \mathrm{HS1}-5$. A fully active $6.5 \mathrm{~kb}$ version of the LCR, called the $\mu \mathrm{LCR}$, has been described. Expression of the $\beta$-like globin genes is absolutely dependent on the presence of the LCR. The developmental expression pattern of the genes in the cluster is achieved through competition of the promoters for the activating function of the LCR. Transgenic mice experiments suggest that subtle changes in the transcription factor environment lead to the successive silencing of the embryonic $\varepsilon$-globin and fetal $\gamma$-globin promoters, resulting in the almost exclusive transcription of the $\beta$-globin gene in adult erythropoiesis. In this paper, we have asked the question whether the LCR and its individual hypersensitive sites 5'HS1-4 can activate a basic promoter in the absence of any other globin sequences. We have employed a minimal promoter derived from the mouse $H$ sp 68 gene driving the bacterial $\beta$-galactosidase (lacZ) gene. The results show that the $\mu \mathrm{LCR}$ and $5^{\prime} \mathrm{HS3}$ direct erythroid-specific, embryonic expression of this construct, while $5^{\prime} \mathrm{HS} 1$, $5^{\prime}$ HS2 and 5'HS4 are inactive at any stage of development. Expression of the $\mu \mathrm{LCR}$ and 5'HS3 transgenes is repressed during fetal stages of development. The transgenes are in an inactive chromatin conformation and the lac $Z$ gene is not transcribed, as shown by in situ hybridization. These data are compatible with the hypothesis that the $L C R$ requires the presence of an active promoter to adopt an open chromatin conformation and with models proposing progressive heterochromatization during embryogenesis. The results suggest that the presence of a $\beta$-globin gene is required for LCR function as conditions become more stringent during development.

Key words: locus control region, $\beta$-globin, lac $Z$ gene, basic promoter, erythropoiesis, embryonic expression pattern, DNaseI hypersensitive sites, transgenic mice, mouse

\section{INTRODUCTION}

The locus control region (LCR) of the human $\beta$-globin multigene cluster is a cis-acting regulatory element present 5-25 $\mathrm{kb}$ upstream of the $\varepsilon$-globin gene. The cluster contains five developmentally regulated genes in the order $5^{\prime}$-embryonic $(\varepsilon)$, fetal $\left(\gamma^{\mathrm{G}}\right.$ and $\left.\gamma^{\mathrm{A}}\right)$ and adult $(\delta$ and $\beta)-3^{\prime}$. The regulatory function of the LCR became first apparent from the study of a Dutch thalassemia (Kioussis et al., 1983) and other naturally occurring deletions of the region where the intact globin gene is not activated (Driscoll et al., 1989; Taramelli et al., 1986). It has been shown that deletion of the LCR not only affects expression of the genes, but also the chromatin structure of the locus over a distance of at least $200 \mathrm{~kb}$ (Forrester et al., 1990).

Chromatin analysis of the LCR showed that it contains a set of developmentally stable DNaseI-hypersensitive sites (HS) termed 5'HS1-5 (Grosveld et al., 1987; Tuan et al., 1985). Various studies have been undertaken to understand the nature and function of this region. These studies revealed that the LCR, when coupled to globin genes in cis, confers high level, copy-number dependent- and position-independent expression to these genes in erythroid tissues in transgenic mice (Grosveld et al., 1987; Ryan et al., 1989; Talbot et al., 1989). 5'HS2-4 also have these properties when linked as single HS to the $\beta$ globin gene (Fraser et al., 1990). Transfection studies stated that only $5^{\prime} \mathrm{HS} 2$ acts as an enhancer in transient assays (Tuan et al., 1989; Moon and Ley, 1991).

A fully active $6.5 \mathrm{~kb}$ version of the LCR containing $5^{\prime} \mathrm{HS} 1-$ 4 , termed the $\mu \mathrm{LCR}$, has been described (Talbot et al., 1989). Further dissection of the $\mu \mathrm{LCR}$ revealed that the activity of each HS can be localized to 200-300 bp core fragments coinciding with the position of hypersensitivity in chromatin (Philipsen et al., 1990; Pruzina et al., 1991; Talbot et al., 1990). The minimal element required for LCR activity of $5^{\prime} \mathrm{HS} 3$ was assigned to a 125 bp fragment (Philipsen et al., 1993). Interestingly, recent observations from our laboratory suggest that $5^{\prime} \mathrm{HS} 3$ is the only site that possesses significant chromatin 
opening activity in single copy transgenic mice (Ellis et al., 1996).

The LCR core fragments all contain binding sites for the erythroid-specific protein GATA-1, and 'GGTGG' or 'CACC' box motifs binding members of the $\mathrm{Sp} 1$ family of transcription factors (Ellis et al., 1993; Philipsen et al., 1990, 1993; Pruzina et al., 1991, 1994; Talbot et al., 1990). This combination of binding sites is also found in the promoters and enhancers of the $\beta$-globin locus as well as many other erythroid-specific genes (Philipsen et al., 1990 and references therein). Hence, we have asked whether the $\mu \mathrm{LCR}$ and its individual HS can function in the absence of any other erythroid regulatory elements. To answer this, we have used the bacterial lacZ gene driven by a non-erythroid, $80 \mathrm{bp}$ minimal promoter derived from the mouse heat shock protein 68 (Hsp68) gene (Kothary et al., 1987, 1988, 1989). The results show that only the $\mu \mathrm{LCR}$ and $5^{\prime} \mathrm{HS} 3$ are able to direct the expression of this gene in the erythroid lineage reproducibly. Interestingly, expression is limited to the embryonic stages of development, after which the chromatin of the transgenes is in an inactive conformation and transcription is repressed. Our data suggest that the presence of a $\beta$-globin gene is essential for LCR function in definitive erythroid cells, implying that there are more stringent requirements for erythroid-specific gene expression in later developmental stages than during the embryonic period.

\section{MATERIALS AND METHODS}

\section{Transgenic mice and embryo collection}

Five different fragments, 5'HS4 (2.1 kb BamHI-XbaI), 5'HS3 (1.9 kb HindIII), 5'HS2 (1.5 kb Asp718-BglII), 5'HS1(1 kb SstI (partial)Hind III) and $\mu$ LCR (6.5 kb, containing 5'HS1-4) (Talbot et al., 1989) were linked to the mouse $H s p 68$ minimal promoter driving the bacterial lacZ reporter gene. Each of these fragments was isolated as described (Kollias et al., 1986). The fragments were dissolved in micro-injection buffer (10 mM Tris-Cl, $\mathrm{pH} 7.5$ and $0.1 \mathrm{mM}$ EDTA) at a concentration of $1-2 \mu \mathrm{g} / \mathrm{ml}$ and microinjected into the pronucleus of FVB fertilized mouse eggs. The injected eggs were transferred into the oviducts of pseudo-pregnant foster females as described (Kollias et al., 1986).

For the 'transient' assay, the foster females were killed 13.5 days after egg transfer and the fetuses were collected from the uterus. For stable lines, transgenic founders were bred to non-transgenic mice. After the lines were established the F1 or F2 males were used for mating with non-transgenic females for the collection of embryos and fetuses at various stages of development.

\section{DNA analysis}

Genomic mouse DNA was prepared from part of the body of the fetuses or tail clips from adult mice. The DNA was cut with EcoRI, Southern blotted and probed with lac $Z$ to detect the transgene. A fragment from the mouse ThyI gene was used as a loading control (Talbot et al., 1990).

\section{DNasel hypersensitive site mapping}

Nuclei were isolated from 8-10 transgenic fetal livers (embryonic day 13.5, E13.5) and DNaseI hypersensitive site mapping was performed as described (Ellis et al., 1996). After this treatment the DNA was isolated and analyzed by digesting with EcoRI. The blots were first hybridized with the Sau3AI-XbaI fragment, coordinates 39819-40269 (Shehee et al., 1989) detecting the hypersensitive site at the promoter of the mouse $\beta$-major gene, and then with the lac $Z$ probe to detect hypersensitive sites at the transgene.

\section{LacZ expression in transgenic embryos and fetuses}

For the collection of mice at various developmental stage, transgenic males from each line were kept with wild-type FVB female mice. The day of the vaginal plug was taken as E0.5. The embryos were dissected out of the decidua and fixed on ice in a solution containing $1 \%$ formaldehyde, $0.5 \%$ glutaraldehyde in PBS for 30 minutes. They were then rinsed in embryo buffer (PBS, $0.02 \%$ NP40, 0.01\% deoxycholate, $2 \mathrm{mM} \mathrm{MgCl}$ ) and incubated in staining solution $(1 \mathrm{mg} / \mathrm{ml}$ 5-bromo-4-chloro-3-indolyl- $\beta$-D-galacto-pyranoside (X-gal), $5 \mathrm{mM}$ $\mathrm{K}_{3} \mathrm{Fe}(\mathrm{CN})_{6}, 5 \mathrm{mM} \mathrm{K} \mathrm{K}_{4} \mathrm{Fe}(\mathrm{CN})_{6}$ and $1 \mathrm{mM}$ ethylene glycol-bis $(\beta$ aminoethyl ether) $\mathrm{N}, \mathrm{N}, \mathrm{N}^{\prime}, \mathrm{N}^{\prime}$-tetraacetic acid (EGTA) in embryo buffer). After 3-4 hours at $37^{\circ} \mathrm{C}$, or overnight at room temperature in the dark, the staining reaction was stopped by removing this solution and rinsing the embryos in PBS. The same procedure was followed for E10.5 and E13.5 blood staining, except that the cells were fixed for only 5 minutes.

\section{In situ hybridization on erythroid cells}

E10.5 embryonic blood from the heart or E13.5 liver cells from individual fetuses were disrupted in 50 and $150 \mu \mathrm{l}$ of PBS respectively. $20 \mu \mathrm{l}$ of this cell suspension was fixed onto a poly(lysine)-coated slide in $4 \%$ formaldehyde, $5 \%$ acetic acid for 20 minutes at room temperature. The cells were then washed $3 \times$ for 10 minutes in PBS and stored in $70 \%$ ethanol at $-20^{\circ} \mathrm{C}$. The remains after collection of blood or liver were stained for $\beta$-galactosidase to detect the transgenics.

Two probes were utilized for in situ hybridization. A nick-translated biotinylated lacZ probe for the detection of lacZ transcription, and DIG-labelled mouse $\alpha$ intron-specific oligonucleotides to reveal the erythroid cells. As a control, some of the slides were RNasetreated and hybridized with these probes. Hybridizations were done as described by Wijgerde et al. (1995) with a few modifications. The lac Z hybridization mix contained 50\% formamide and $10 \%$ dextran sulphate. For antibody detection, the Tyramid amplification system TSA of Dupont was used (Raap et al., 1995).

\section{Tissue culture and cell transfection}

Murine erythroleukemia cells (MEL, strain C88) were maintained in DMEM plus $10 \%$ fetal calf serum. The construct $\mu \mathrm{LCR}-$ lac $Z$ with neomycin as selectable marker was linearized at the $S c a I$ site and transfected by electroporation as described (Antoniou et al., 1988; Antoniou and Grosveld, 1990). Stably transfected MEL populations were selected in G418 and induced to undergo erythroid differentiation by the addition of DMSO to a final concentration of $2 \%(\mathrm{v} / \mathrm{v})$ for 2 days. The cells were collected and used for hypersensitive-site mapping. The DNaseI-treated samples were cut with EcoRI and SacII. The Southern blots were hybridized with the $1.9 \mathrm{~kb}$ fragment of $5^{\prime} \mathrm{HS} 3$ (Talbot et al., 1989) or the lacZ probe to detect the hypersensitive sites.

\section{RESULTS}

\section{Expression status of lac $Z$ transgenes in mice as analyzed by X-gal staining}

In order to analyze the expression status of the LCR and its individual hypersensitive sites (HS) with a ubiquitous promoter, each of these sites (Talbot et al., 1989) was linked to the minimal mouse $H s p 68$ promoter. This $80 \mathrm{bp}$ promoter contains a CCAAT box, an Sp1 binding site and a TATA box. All these constructs used the bacterial $\beta$-galactosidase (lacZ) gene as a reporter, to allow visualization of expression by $\mathrm{X}$ gal staining (Bonnerot and Nicolas, 1993). These constructs were first tested in transgenic founder animals. Fetuses and yolk sacs were collected at 13.5 days of development (henceforth referred to as E13.5) and analyzed by X-gal staining All 
Table 1. X-gal staining of transgenic founder fetuses at E13.5

\begin{tabular}{lccc}
\hline Construct & $\begin{array}{c}\text { Number of } \\
\text { transgenic fetuses }\end{array}$ & $\begin{array}{c}\text { X-gal staining in blood, } \\
\text { yolk sac and fetal liver }\end{array}$ & $\begin{array}{c}\text { Position } \\
\text { effect }\end{array}$ \\
\hline 5'HS1-lacZ & 5 & 2 & 3 \\
5'HS2-lacZ & 7 & 0 & 7 \\
5'HS3-lacZ & 6 & 5 & 1 \\
5'HS4-lacZ & 11 & 4 & 7 \\
$\mu \mathrm{LCR}-$ lacZ & 12 & 10 & 7
\end{tabular}

'Position effect' indicates ectopic expression, i.e. outside the erythroid system.

fetuses were typed for the transgene by Southern blot hybridization. The results are summarized in Table 1.

LacZ expression was observed in blood, yolk sac and fetal liver of a few founder animals containing constructs with $5^{\prime} \mathrm{HS} 1$ or $5^{\prime} \mathrm{HS} 4$. However, no hematopoietic-specific staining was observed in founder fetuses with $5^{\prime} \mathrm{HS} 2$. In most of the $5^{\prime} \mathrm{HS} 1,5^{\prime} \mathrm{HS} 2$ and $5^{\prime} \mathrm{HS} 4$ founders, X-gal staining was observed in various other parts of the fetuses. This type of staining corresponds to classical position effects, to which the minimal Hsp68 promoter is very sensitive (Kothary et al., 1987, 1988, 1989). These position effects show that the transgenes are functional and have not integrated in an inherently closed chromatin domain of the mouse genome. In sharp contrast, X-gal staining could be easily detected in the erythroid cells of the yolk sac, fetal liver and blood vessels in the majority of founder fetuses with either the $\mu \mathrm{LCR}$ or the 5'HS3 transgene. As expected, ectopic expression was also observed, since the LCR or parts of it do not neutralize position effects in non-erythroid tissues (Grosveld et al., 1987).

Previously, it has been shown that each of the hypersensitive sites of the LCR may have some developmental specificity (Fraser et al., 1993), and hence it was possible that the absence of erythroid staining in the 5 'HS $1,-2$ and -4 founder fetuses is due to the stage specificity of these individual sites. Therefore, we studied the expression of the constructs in stable transgenic lines at different developmental stages. The data for each of the established stable transgenic lines are summarized in Table 2. F1 or F2 males from these lines were mated with non-transgenic
Table 2. X-gal staining of transgenic lines

\begin{tabular}{lccc}
\hline Construct & Lines & $\begin{array}{c}\text { X-gal staining in } \\
\text { embryonic erythroid } \\
\text { cells E8.5-E10.5 }\end{array}$ & $\begin{array}{c}\text { Position } \\
\text { effect }\end{array}$ \\
\hline 5'HS1-lacZ & a & No & Yes \\
5'HS2-lacZ & a & No & Yes \\
& b & No & Yes \\
& c & No & Yes \\
5'HS3-lacZ & d & No & No \\
& a & Yes & Yes \\
5'HS4-lacZ & b & Yes & No \\
& a & No & Yes \\
& b & No & No \\
& c & No & Yes \\
& d & No & Yes \\
& a & Yes & Yes \\
& b & Yes & No
\end{tabular}

'Position effect' indicates ectopic expression, i.e. outside the erythroid system.

females to collect embryos and fetuses at different developmental time points.
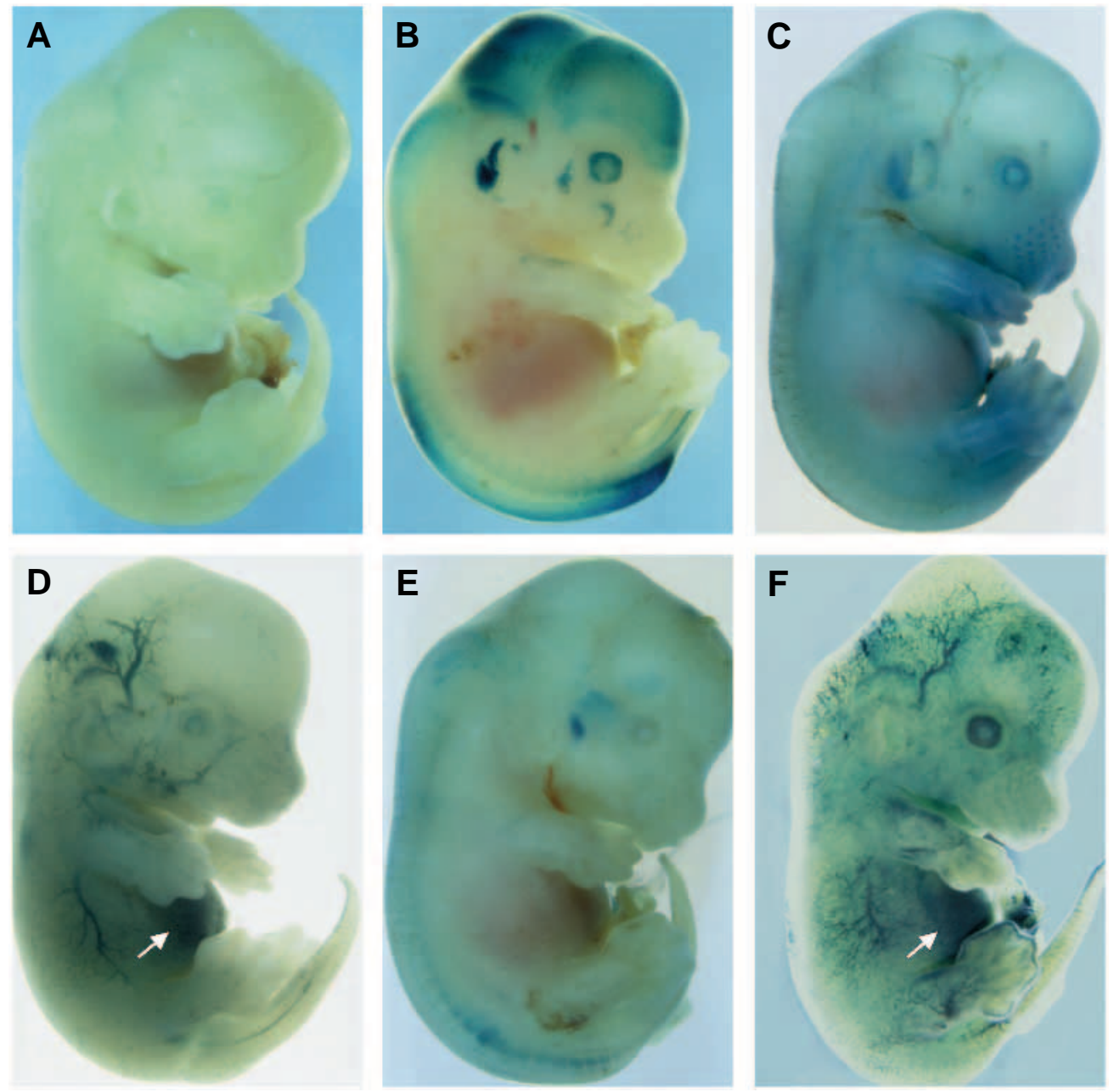

Fig. 1. X-gal-stained E13.5 transgenic fetuses from stable transgenic lines. (A) Control non-transgenic fetus; (B) 5'HS1-lacZ; (C) 5'HS2-lacZ; (D) 5'HS3-lacZ; (E) 5'HS4-lacZ; and (F) $\mu L C R-l a c Z$. The fetal liver is indicated with an arrow in $\mathrm{D}$ and $\mathrm{F}$. Ectopic expression, i.e. expression outside the erythroid system, can be seen in B, C and E. Original magnification, $8 \times$. 
These results revealed that, at E13.5, X-gal staining of the erythroid cells could only be detected in the transgenic lines containing the $\mu \mathrm{LCR}$ or $5^{\prime} \mathrm{HS} 3$ constructs (Fig. 1D,F). This is in agreement with the data obtained from the founder fetuses (Table 1). Staining of the erythroid system was not seen for the other constructs (Fig. 1B,C,E). Again, expression outside the erythroid system, due to position effects, was observed in many of the lines with all of the constructs (Fig. 1 and Tables 1,2).

The expression status of the transgenes at earlier stages in mouse development was examined by X-gal staining of embryos at various time points starting from the onset of hematopoiesis at E7.5-8. Embryos containing the 5'HS1, 5'HS2 and 5'HS4 transgenes showed no staining in the yolk sac or blood cells at any of the stages examined (Table 2). However, the $\mu \mathrm{LCR}$ and 5'HS3 lines showed the first erythroid-specific staining at E8-8.5, with a ring of blue cells observed at the base of the yolk sac (Fig. 2B, arrow). Later, X-gal staining cells are found over the entire yolk sac (Fig. 2C,D). In E9E10.5 embryos, the staining is seen in the cells within the blood capillaries (Fig. 2E-G), the heart (Fig. 2G, arrows) and the dorsal aorta (Fig. 2G, arrowheads). In addition, staining of the fetal liver is observed in E13.5 fetuses (Fig. 1D,F, arrows). Surprisingly, very few blue cells are found in adult blood from the same transgenic lines (Fig. 3A). This prompted us to study the blood from E10.5 and E13.5 transgenics in more detail. While $>98 \%$ of the cells are lacZ-positive in E10.5 blood (Fig. 3F), this number decreases to around $50 \%$ in E13.5 blood (Fig. 3E). Most of the cells staining at the early stages are presumably embryonic primitive erythroid cells, since they are large and nucleated (Fig. 3E,F). Strikingly, less than $10 \%$ lacZ-positive cells are found in the fetal liver (Fig. 3C), the site of erythropoiesis at E13.5 (see Fig. 1D,F, arrows). These data therefore suggest that the $\mu \mathrm{LCR}$ and $5^{\prime} \mathrm{HS} 3$ transgenes are active in primitive cells of embryonic the $\mu \mathrm{LCR}$-lac $Z$ lines. origin, but not in fetal- and adult-type definitive erythroid cells.

\section{DNasel hypersensitive site mapping in the fetal liver of lacZ transgenic mice}

The LCR is characterized by the presence of developmentally stable, very strong, erythroid-specific DNaseI hypersensitive sites (Grosveld et al., 1987; Jimenez et al., 1992b; Tuan et al., 1985). To determine whether these hypersensitive sites are correctly established in our transgenic mice, we examined the chromatin structure in E13.5 liver of the lacZ transgenic lines described above. Nuclei from the livers of E13.5 fetuses were
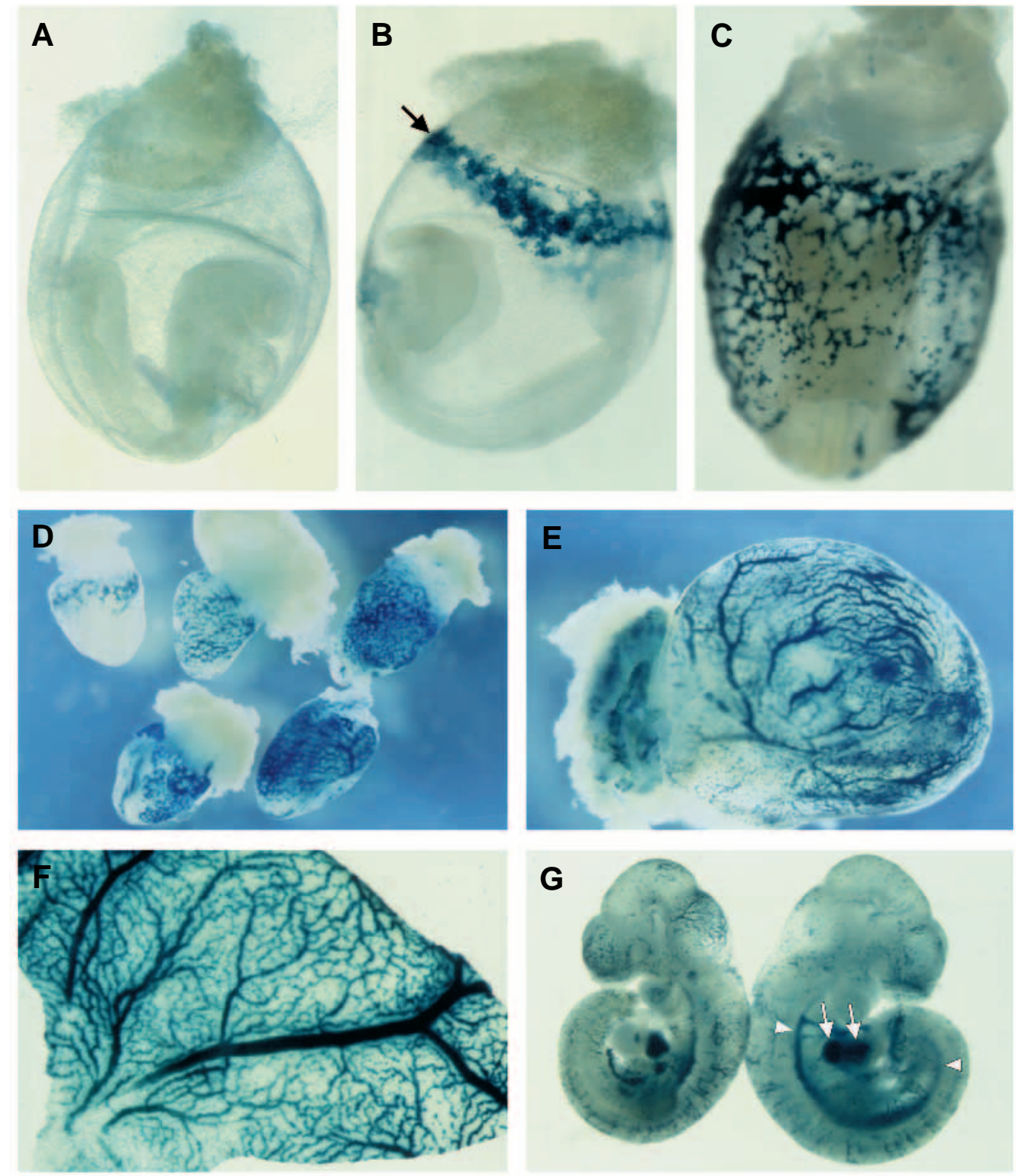

Fig. 2. Developmental (E8-E11.5) X-gal staining pattern in the 5'HS3-lacZ line b. (A) Non-transgenic E8 embryo. (B) E8 transgenic embryo; the ring of blue cells at the base of the yolk sac is indicated by an arrow. (C) E8.5 transgenic embryo. (D) Various stages observed in E8-8.5 transgenic embryos. (E) E9.5 transgenic embryo enclosed in the yolk sac. (F) E10.5 yolk sac staining. (G) E10.5 (left) and E11.5 (right) transgenic embryos; the heart is indicated by arrows, the dorsal aorta by arrowheads. Original magnification, $80 \times(\mathrm{A}, \mathrm{B}, \mathrm{C}, \mathrm{F}) ; 25 \times(\mathrm{D}, \mathrm{G}) ; 50 \times(\mathrm{E})$. Data are shown for the $5^{\prime} \mathrm{HS} 3$-lacZ line b in Figs 2,3 and 5 , but it should be noted that identical results were obtained with the other $5^{\prime} \mathrm{HS} 3-$ lacZ and both of 
treated with DNaseI (Ellis et al., 1996), after which the purified DNA was digested with EcoRI and Southern-blotted. As a control, the Southern blots were first hybridized with a probe detecting the hypersensitive site at the mouse $\beta$-major promoter to assess DNaseI sensitivity. The blots were then hybridized with a lac $Z$ probe to detect hypersensitive sites at the transgenes. As a reference, tail DNA from each transgenic mouse line was cut with EcoRI and NcoI to show the position of the Hsp68 promoter. To mark the positions of the core elements of the LCR fragments, EcoRI-digested tail DNA was recut with SpeI for 5'HS1, HindIII for 5'HS2, ApaI for 5'HS3 and SphI for 5'HS4 (Talbot et al., 1989).

The results obtained from this analysis on E13.5 liver show that hypersensitive sites are not detectable at the correct positions within any of the transgenes, while the hypersensitive site at the mouse $\beta$-major promoter could be detected consistently (Fig. 4). For example, the weak sensitivity seen in DNA from the $5^{\prime} \mathrm{HS} 2$-lacZ line b (grey arrow in Fig. 4D) does not map to the core fragment of $5^{\prime} \mathrm{HS} 2$, nor to the Hsp68 promoter and most likely reflects the general, non-erythroid, DNaseI sensitivity associated with $5^{\prime} \mathrm{HS} 2$ (e.g. Ellis et al., 1996). These results are not surprising for the lines with the $5^{\prime} \mathrm{HS} 1,-2$ and -4 constructs, since we could not detect erythroid-specific expression of the lac $Z$ gene in these mice. However, no DNaseI hypersensitivity is observed in the DNA from the lines with the $\mu \mathrm{LCR}$ and $5^{\prime} \mathrm{HS} 3$ constructs (Fig. 4B,E), even though lacZ protein is easily detectable at this stage (Fig. 1D,F; Fig. 3C). Since it is possible that the lac Z gene was transcribed only at earlier stages in fetal liver development, we repeated the DNaseI fade-out analysis on E12.5 livers of the $\mu \mathrm{LCR}$ and 5'HS3 lines. These results were also negative (data not shown) and thus, we conclude that the transgenes are in a closed chromatin conformation in the fetal liver.

\section{In situ hybridization to detect active transcription of the transgene}

Since the numbers of erythroid cells that can be obtained from E8.5-E10.5 embryos are too small for a DNaseI sensitivity analysis (N. Gillemans, unpublished results), we used in situ hybridization as an alternative to monitor the activity of the $\mu \mathrm{LCR}$ and $5^{\prime} \mathrm{HS} 3$ transgenes. To more closely examine when and at what frequency the $\mu \mathrm{LCR}$ - and $5^{\prime} \mathrm{HS} 3-$ lacZ transgenes are actively transcribed, we analyzed specific transcription of the lac $Z$ gene at the single cell level (Wijgerde et al., 1995). In situ hybridization was performed on erythroid cells from E10.5 blood and E13.5 liver with a biotin-labelled lacZ
Table 3. Percentage of cells actively transcribing the lacZor the endogenous mouse $\alpha$-globin genes as determined by in situ hybridization

\begin{tabular}{|c|c|c|c|c|}
\hline $\begin{array}{l}\text { Time } \\
\text { points }\end{array}$ & Cell type & Line & $\begin{array}{c}\text { Percentage of } \\
\text { cells with lacZ } \\
\text { nuclear signal }\end{array}$ & $\begin{array}{l}\text { Percentage of } \\
\text { cells with } \\
\text { mouse } \alpha \text {-globin } \\
\text { nuclear signals }\end{array}$ \\
\hline E10.5 & Blood & $\begin{array}{l}5^{\prime} \mathrm{HS} 3-l a c Z \text { b } \\
\mu \mathrm{LCR}-l a c Z \text { b }\end{array}$ & $\begin{array}{l}16 \\
15\end{array}$ & $\begin{array}{l}92 \\
97\end{array}$ \\
\hline E13.5 & Fetal liver & $\begin{array}{l}5^{\prime} \mathrm{HS} 3-l a c Z \text { b } \\
\mu \mathrm{LCR}-l a c Z \mathrm{~b}\end{array}$ & $\begin{array}{l}0.5 \\
1.1\end{array}$ & $\begin{array}{l}97 \\
95\end{array}$ \\
\hline
\end{tabular}

probe to detect transcription of the transgenes. Oligonucleotide mouse $\alpha$-globin probes were used to establish the number of erythroid cells in each preparation. The slides were analyzed by confocal-or standard fluorescence microscopy.

When lac $Z$ was used as probe, we observed a single nuclear signal in a significant number (around 15\%) of cells in E10.5 blood (Table 3; Fig. 5A, arrow). The much higher percentage
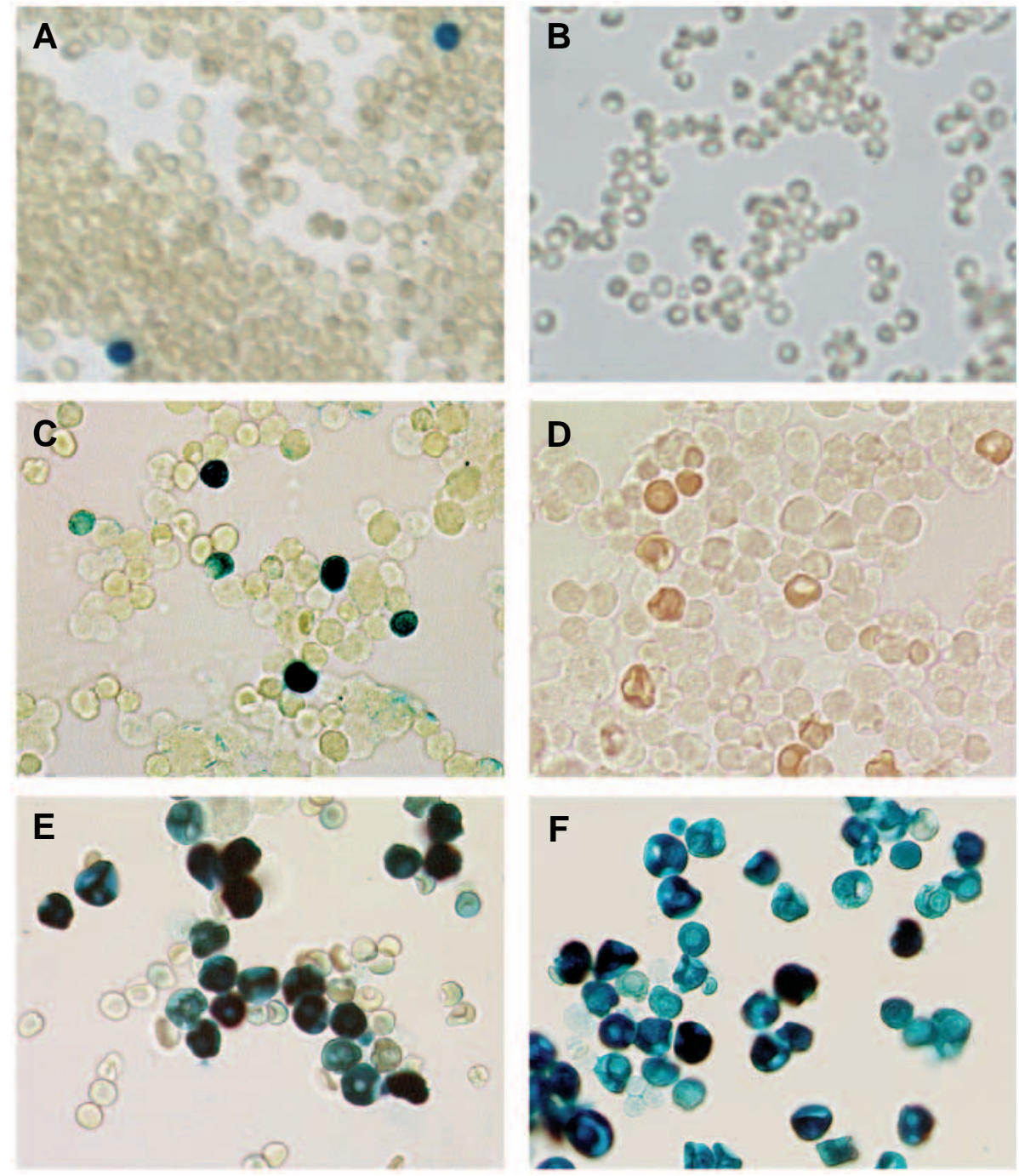

Fig. 3. X-gal staining of blood and fetal liver cells from the 5'HS3-lacZ line b.

(A) Transgenic adult blood; (B) non-transgenic adult blood; (C) E13.5 transgenic liver cells; (D) E13.5 non-transgenic liver cells; (E) E13.5 transgenic blood; and (F) E10.5 transgenic blood. Original magnification, 400x. 
of X-gal staining cells (Fig. 3F) suggests that the lacZ gene may not be transcribed continuously, as has been observed in transgenic mice carrying the human $\beta$-globin locus with small deletions in the LCR (Milot et al., 1996). Hence, we conclude that the hemizygous lac $Z$ gene is actively transcribed at this stage. Contrasting observations were made with E13.5 liver cells where only a few cells $(0.5-1 \%)$ had a nuclear signal (Table 3 and Fig. 5B). The control hybridization for expression of the homozygous mouse $\alpha$-globin genes detected two nuclear signals in $>90 \%$ of the cells (Table 3 ; Fig. 5C, arrowheads), confirming that these cells are of the erythroid lineage. No nuclear signal was detected in RNase-treated or lacZ- negative cells at either stage when hybridized with the lacZ probe (Fig. 5D and data not shown). Thus, we conclude that at E10.5, many of the erythroid cells from the $\mu \mathrm{LCR}$ and $5^{\prime} \mathrm{HS} 3$ lines are actively transcribing the lac $Z$ gene. As development advances, the percentage of actively transcribing cells becomes considerably lower. This is in agreement with our DNaseI fade-out analysis, in which $<1 \%$ of cells with an active gene in E13.5 liver would be too low to detect hypersensitive sites at the transgene.

\section{DNasel hypersensitive site mapping in MEL cell populations with $\mu$ LCR-lacZ}

The absence of hypersensitive sites in the $\mu \mathrm{LCR}$-lacZ and $5^{\prime} \mathrm{HS} 3$-lacZ transgenes raised the question whether these constructs are intrinsically inactive in the adult erythroid environment. To investigate this, we transfected the $\mu \mathrm{LCR}-$ lac $Z$ construct into murine erythroleukemia (MEL) cells. These cells represent the pro-erythroblast stage of adult cell differentiation. Stable clones were obtained by selection with G418, thus assuring integration into an active area of the chromatin. The cell populations were expanded and induced with DMSO to undergo erythroid differentiation for 2 days. These cells were then analyzed for DNaseI sensitivity, as described earlier (Philipsen et al., 1990). The blots were hybridized with a $5^{\prime} \mathrm{HS} 3$ probe, because the lacZ probe hybridizes to vector sequences precluding a straightforward interpretation of the results (not shown). Interestingly, we find that all four DNaseI hypersensitive sites are strongly represented, as shown in Fig. 6. The sub-band corresponding to the hypersensitive site at $5^{\prime} \mathrm{HS} 4$ runs just below the parent restriction band and is not well resolved. However, the hypersensitive sites at $5^{\prime} \mathrm{HS} 1$ and the promoter (which comigrate), $5^{\prime} \mathrm{HS} 2$ and $5^{\prime} \mathrm{HS} 3$ are found. Thus, we conclude that the $\mu \mathrm{LCR}-\mathrm{lac} Z$ construct is not intrinsically inactive in the adult erythroid environment.

\section{DISCUSSION}

\section{Activation of lacZ transgenes by the $\beta$-globin LCR}

Previous studies involving the human $\beta$-globin LCR and its individual hypersensitive sites $5^{\prime} \mathrm{HS} 1-4$ have shown that these regulatory elements confer position-independent, copynumber dependent expression to the $\beta$-globin gene in transgenic mice (Caterina et al., 1991, 1994; Ellis et al., 1993; Fraser et al., 1990; Philipsen et al., 1990, 1993; Pruzina et al., 1991, 1994; Ryan et al., 1989; Talbot et al., 1990). It has not been established whether the LCR can direct erythroid-specific expression in the absence of any globin gene sequences. We linked the $\mu \mathrm{LCR}$ or individual HS elements to a simple $80 \mathrm{bp}$ promoter derived from the mouse Hsp68 gene that does not have any developmental or tissue specificity (Kothary et al., 1987, 1988, 1989).

We analyzed the ability of the $\mu \mathrm{LCR}$ and $5^{\prime} \mathrm{HS} 1,5^{\prime} \mathrm{HS} 2$,

A

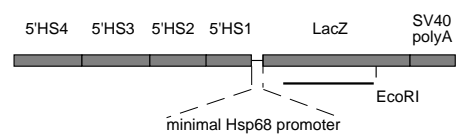

C

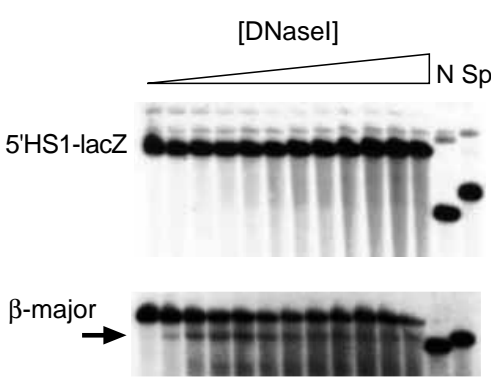

E

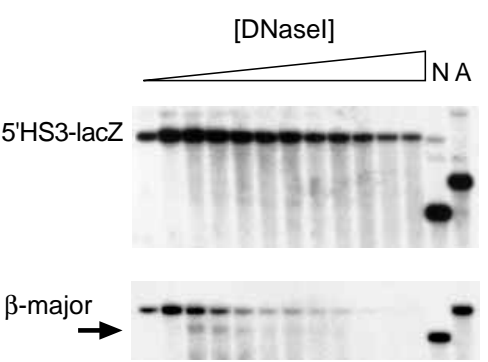

Fig. 4. DNaseI hypersensitive site mapping. (A) Schematic drawing of the $\mu \mathrm{LCR}-\mathrm{lac} Z$ construct. The probe is indicated with a bar. (B-F) Hypersensitive site analysis in e13.5 liver of transgenic lines. The DNA was digested with EcoRI (see Materials and Methods). For each line, a control hybridization detecting the hypersensitive site at the promoter of the mouse $\beta$-major gene is shown below. The triangles indicate increasing amounts of DNaseI. Hypersensitive sites are indicated by arrows. (B) $\mu \mathrm{LCR}$-lacZ line b; (C) 5'HS1-lacZ line a; (D) 5'HS2-lacZ line b; (E) 5'HS3-lacZ line b; (F) 5'HS4-lacZ line a. Control lanes contain DNA digested with EcoRI plus another enzyme to mark the position of the Hsp68 promoter or the LCR regions where hypersensitive sites should appear: N, NcoI (Hsp68 promoter), Sp, SpeI (5’HS1), H, HindIII (5’HS2), A, ApaI (5'HS3), S, SphI (5’HS4). 

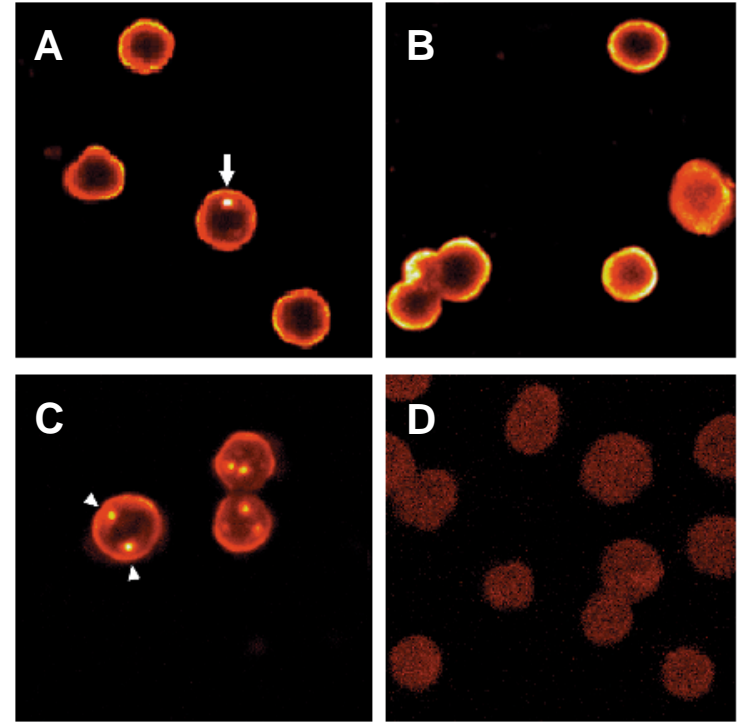

Fig. 5. In situ hybridization to detect active transcription of the lac $Z$ transgene in the $5^{\prime} \mathrm{HS} 3$-lacZ line b. (A) E10.5 embryonic blood hybridized with the lac $Z$ probe. A single nuclear signal corresponding to active transcription of the hemizygous lacZ gene is indicated by an arrow. (B) E13.5 fetal liver cells hybridized with the lacZ probe; there are virtually no cells with nuclear signal (Table 3 ). (C) Control hybridization with oligonucleotide probes detecting transcription of the homozygous mouse $\alpha$-globin gene; two transcription foci per nucleus are indicated by arrowheads. (D) E10.5 blood from a control non-transgenic mouse hybridized with the lac $Z$ probe. Original magnification, 630×.

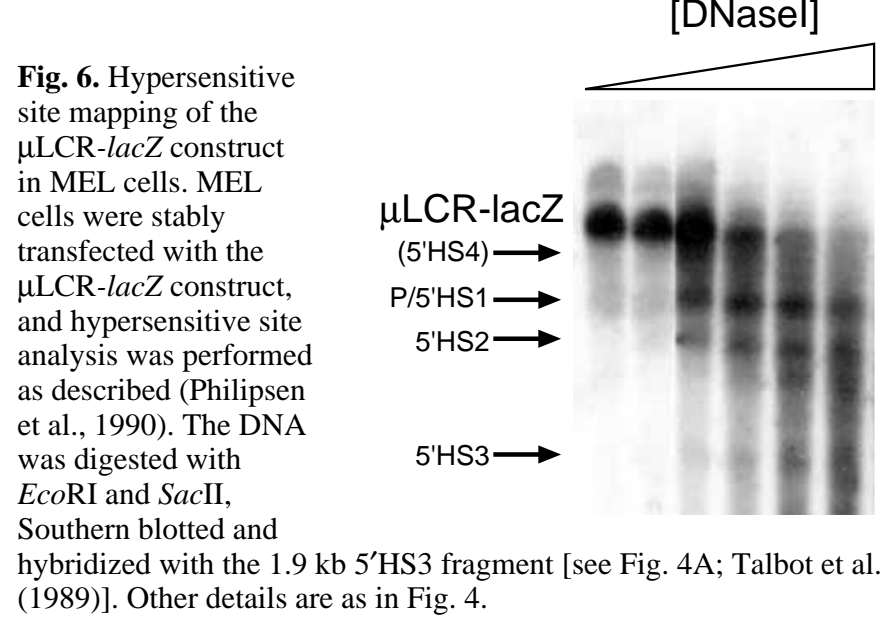

$5^{\prime} \mathrm{HS} 3$ and $5^{\prime} \mathrm{HS} 4$ to activate this reporter construct in the erythroid cells of transgenic mice. The results show that only the complete $\mu \mathrm{LCR}$ and $5^{\prime} \mathrm{HS} 3$ can direct expression of the $l a c Z$ reporter in the erythroid system of the developing mouse. While erythroid-specific staining was observed in some of the E13.5 founder fetuses analyzed for 5'HS1 and 5'HS4, none of the established transgenic lines with these constructs showed such a staining at any stage of development. This indicates that $5^{\prime} \mathrm{HS} 1$ and 5'HS4 need other elements to activate erythroidspecific transcription.

$5^{\prime} \mathrm{HS} 2$ is believed to be a crucial component of the LCR.
This part of the LCR shows the highest degree of evolutionary conservation (Hardison et al., 1993; Jimenez et al., 1992a). Its function has been studied in great detail in transfection (Hardison et al., 1993; Moon and Ley, 1991; Tuan et al., 1989), transgenic (Caterina et al., 1991, 1994; Ellis et al., 1993, 1996; Ryan et al., 1989; Talbot et al., 1990) and knockout experiments (Fiering et al., 1995). To our surprise, we could not detect any erythroid-specific expression with the construct containing $5^{\prime} \mathrm{HS} 2$, neither in E13.5 day founders, nor at any stage of development in four established lines. Thus we conclude that $5^{\prime} \mathrm{HS} 2$ is also unable to activate the nonerythroid $H s p 68$ promoter in the erythroid lineage. The frequently observed ectopic expression (i.e. expression outside the erythroid cells) in $5^{\prime} \mathrm{HS} 2$ transgenics shows that this construct is not intrinsically inactive. Rather, these results suggest that $5^{\prime} \mathrm{HS} 2$ is dependent on local elements provided by the $\beta$-globin gene for erythroid-specific activation. Preliminary data show that these elements might reside within the first $800 \mathrm{bp}$ of the $\beta$-globin promoter, since we have one E13.5 founder with $5^{\prime} \mathrm{HS} 2$ and the 5'-800 $\beta$-globin promoter driving the lac $Z$ gene that shows extensive staining of the erythroid system (not shown).

It should be noted that all the transgenes were present as multi-copy concatamers. Previous studies from our laboratory have shown that only $5^{\prime} \mathrm{HS} 3$ of the LCR is capable of activating the $\beta$-globin gene in single-copy transgenic mice. 5'HS2 was only active when present in a multi-copy configuration (Ellis et al., 1996). In contrast, it appears from the present study that $5^{\prime} \mathrm{HS} 2$ is not able to activate the minimal Hsp68 promoter, even in multi-copy transgenics. Our data corroborate those of Ellis et al. (1996) that $5^{\prime} \mathrm{HS} 3$ is the most important hypersensitive site of the $\beta$-globin LCR.

\section{Developmental expression pattern of the lacZ transgenes}

In the lines with the $\mu \mathrm{LCR}$ or $5^{\prime} \mathrm{HS} 3$, expression of the lacZ transgene could first be detected at E8-8.5 as a ring of cells around the base of the yolk sac. This is the first site of erythropoiesis in the developing mammalian embryo (Russell and Bernstein, 1966). Later, as vascularization occurs, lacZ-positive cells are found in the developing circulatory system of the embryo. In E10.5-11 blood, the vast majority of the circulating primitive erythrocytes are lacZ-positive. A paradox occurs in E13.5 liver. Although the erythroid fetal liver can be easily stained for the presence of the lac $Z$ protein, large numbers of erythrocytes begin to appear in the circulation that do not stain with X-gal. We believe that these data can be explained by the model for the development of the hematopoietic system proposed by Dzierzak and Medvinsky (1995). According to this model, the fetal liver is first colonized by a wave of primitive hematopoietic precursor cells derived from the yolk sac. A second wave of colonization occurs when definitive stem cells originating from the AGM (Aorta, Gonads, Mesonephros) region migrate to the fetal liver. In our transgenic mice, the lacZ-positive cells in the fetal liver would be derived from the yolk sac precursor cells. These cells actively expressed the transgene at the embryonic stages of development. Although they have switched off the lacZ gene in the E13.5 fetal liver, as we have shown by in situ hybridization, they still contain lacZ protein and mRNA. Hence, these cells may stain lacZ-positive even after a number of cell divisions. The lacZ-negative cells 
in the circulation would be derived from fetal liver cells originating from the AGM region, which have never expressed the lac $Z$ gene at detectable levels. This model implies that the lac $Z$ gene has a repressive effect on the LCR in definitive but not in primitive erythropoiesis. Recent observations of Guy et al. (1996) and Robertson et al. (1995) are consistent with this hypothesis, and preclude the simple explanation that our observations are an artefact of the particular transgene construct that we have used. These authors found that the presence of the lacZ gene, even in the presence of a complete $\beta$-globin gene (Guy et al., 1996), interferes with LCR function (Robertson et al., 1995). Unfortunately, these groups did not present data on early embryonic time points. The absence of DNaseI hypersensitive sites in E13.5 fetal liver suggests that the repression is due to heterochromatization of the transgenes (Adams and Workman, 1993; Elgin, 1990; Hebbes et al., 1992; Patterton and Wolffe, 1996), and not caused by the inability of the LCR to interact with the model promoter we employed. Recent data of knockout experiments in the mouse $\beta$-globin locus show that nonerythroid promoters can be activated very efficiently by the LCR (Fiering et al., 1995; Hug et al., 1996; Kim et al., 1992; Nandi et al., 1988; Shehee et al., 1993). Consistent with these observations, we can detect hypersensitive sites at the transgene when transfected into MEL cells. Mechanistically, the lacZ gene could serve as a nucleation point for heterochromatization in definitive erythroid cells, resulting in repression of the transgenes in mice. In tissue culture, these events are eliminated because the selection procedure only leaves cells in which integration has occurred in open areas of chromatin, to allow expression of the resistance marker. The results suggest that the $\mu \mathrm{LCR}-$ lac $Z$ construct is active when integrated in such chromatin in adult erythroid cells, but that it is suppressed when it integrates in closed chromatin domains, as is probably the case in transgenic mice. The reason for the inactivation in mice is presently unknown, but we have ruled out the possibility that it is caused by progressive methylation of the transgenes (results not shown).

Previous studies have shown that the $\mu \mathrm{LCR}$ and $5^{\prime} \mathrm{HS} 3$ direct high level expression of the $\beta$-globin gene in transgenic mice (Ellis et al., 1996; Philipsen et al., 1990, 1993; Talbot et al., 1989); the data in this paper indicate that the presence of this gene is a requirement for the activity of the $\mu \mathrm{LCR}$ and $5^{\prime} \mathrm{HS} 3$ in fetal and adult erythroid cells.

\section{Hypersensitive site formation in the LCR}

Our data are in apparent contradiction with a number of published observations regarding hypersensitive site formation in the LCR. Two independent laboratories have studied this for $5^{\prime} \mathrm{HS} 2$ and $5^{\prime} \mathrm{HS} 4$. In the case of $5^{\prime} \mathrm{HS} 2$, Pawlik et al. (1995) have shown that $5^{\prime} \mathrm{HS} 2$, in the absence of a gene, has a DNaseIhypersensitive site in transgenic mice. We also observe weak hypersensitivity at $5^{\prime} \mathrm{HS} 2$ in our transgenic lines, and suggest that this corresponds to the ubiquitous hypersensitive site associated with the human 5'HS2 (Ellis et al., 1996). This hypersensitive site is located outside the core fragment of $5^{\prime} \mathrm{HS} 2$, where the erythroid-specific activity resides.

Transgenic mice experiments also suggest that $5^{\prime} \mathrm{HS} 4$ can autonomously form a hypersensitive site (Lowrey et al., 1992). However, since only one transgenic line was analyzed in this study, the transgene may have integrated in an area of open chromatin. Stamatoyannopoulos et al. (1995) have reported on the formation of $5^{\prime} \mathrm{HS} 4$ in the presence of $5^{\prime} \mathrm{HS} 3$ in transfection experiments in MEL cells. As we show here, we can detect hypersensitive sites when we transfect the $\mu \mathrm{LCR}-$ lac $Z$ construct into MEL cells, but not in the transgenic lines.

Our data are compatible with those obtained for the chicken $\beta$-globin locus in transgenic mice. These data suggest that hypersensitive site formation in the chicken $3^{\prime}$ enhancer is dependent on the presence of an active promoter (Reitman et al., 1993). We have shown that in E13.5 fetal liver the $\mu$ LCR and $5^{\prime} \mathrm{HS} 3$ transgenes are in a closed chromatin conformation, and that transcription of the lac $Z$ gene is not detectable in these cells. Hence, as in the chicken case (Reitman et al., 1993), a closed promoter correlates with the absence of hypersensitive sites in the LCR.

\section{Perspective}

The data in this paper show that the $\mu \mathrm{LCR}$ and $5^{\prime} \mathrm{HS} 3$ can activate the minimal $H s p 68$ promoter in transgenic mice. The other HS elements of the LCR are inactive and therefore require additional elements of the $\beta$-globin locus for their activity. The expression of the $\mu \mathrm{LCR}$ and $5^{\prime} \mathrm{HS} 3$ transgenes is specific for embryonic, primitive erythropoiesis. Hence, these mice are useful tools for the study of these first erythroid cells. Recently, gene-targeting experiments have implicated a number of transcription factors in the development of the erythroid cell (reviewed in Shivdasani and Orkin, 1996). The role of these transcription factors in the activating function of the $\mu \mathrm{LCR}$ and $5^{\prime} \mathrm{HS} 3$ in primitive erythropoiesis can now be addressed directly by breeding our transgenes into these knockout backgrounds.

We would like to thank Drs Elaine Dzierzak and Dies Meijer for their thoughtful comments on the manuscript, Ms An Langeveld for help with the in situ hybridizations, Mirko Kuit for his expert help with photography, and Adriaan Houtsmuller for confocal microscopy. This work was supported by an NWO grant to F.G.

\section{REFERENCES}

Adams, C. C. and Workman, J. L. (1993). Nucleosome displacement in transcription. Cell 72, 305-8.

Antoniou, M., deBoer, E., Habets, G. and Grosveld, F. (1988). The human beta-globin gene contains multiple regulatory regions: identification of one promoter and two downstream enhancers. EMBO J. 7, 377-84.

Antoniou, M. and Grosveld, F. (1990). beta-globin dominant control region interacts differently with distal and proximal promoter elements. Genes Dev. 4, 1007-13.

Bonnerot, C. and Nicolas, J.-F. (1993). Application of lacZ gene fusions to postimplantation development. Meth. Enzymol. 225, 451-469.

Caterina, J. J., Ciavatta, D. J., Donze, D., Behringer, R. R. and Townes, T. M. (1994). Multiple elements in human beta-globin locus control region $5^{\prime}$ HS 2 are involved in enhancer activity and position-independent, transgene expression. Nucleic Acids Res. 22, 1006-11.

Caterina, J. J., Ryan, T. M., Pawlik, K. M., Palmiter, R. D., Brinster, R. L., Behringer, R. R. and Townes, T. M. (1991). Human beta-globin locus control region: analysis of the 5' DNase I hypersensitive site HS 2 in transgenic mice. Proc. Natl Acad. Sci. USA 88, 1626-30.

Driscoll, M. C., Dobkin, C. S. and Alter, B. P. (1989). Gamma delta betathalassemia due to a de novo mutation deleting the $5^{\prime}$ beta-globin gene activation-region hypersensitive sites. Proc. Natl Acad. Sci. USA 86, 7470-4.

Dzierzak, E. and Medvinsky, A. (1995). Mouse embryonic hematopoiesis. Trends Genet. 11, 359-66.

Elgin, S. C. (1990). Chromatin structure and gene activity. Curr. Opin. Cell Biol. 2, 437-45.

Ellis, J., Talbot, D., Dillon, N. and Grosveld, F. (1993). Synthetic human 
beta-globin $5^{\prime} \mathrm{HS} 2$ constructs function as locus control regions only in multicopy transgene concatamers. EMBO J. 12, 127-34.

Ellis, J., Tan-Un, K. C., Harper, A., Michalovich, D., Yannoutsos, N., Philipsen, S. and Grosveld, F. (1996). A dominant chromatin-opening activity in $5^{\prime}$ hypersensitive site 3 of the human beta-globin locus control region. EMBO J. 15, 562-568.

Fiering, S., Epner, E., Robinson, K., Zhuang, Y., Telling, A., Hu, M., Martin, D. I., Enver, T., Ley, T. J. and Groudine, M. (1995). Targeted deletion of $5^{\prime} \mathrm{HS} 2$ of the murine beta-globin LCR reveals that it is not essential for proper regulation of the beta-globin locus. Genes Dev. 9, 220313.

Forrester, W. C., Epner, E., Driscoll, M. C., Enver, T., Brice, M., Papayannopoulou, T. and Groudine, M. (1990). A deletion of the human beta-globin locus activation region causes a major alteration in chromatin structure and replication across the entire beta-globin locus. Genes Dev. $\mathbf{4}$, $1637-49$.

Fraser, P., Hurst, J., Collis, P. and Grosveld, F. (1990). DNaseI hypersensitive sites 1, 2 and 3 of the human beta-globin dominant control region direct position-independent expression. Nucleic Acids Res. 18, 35038.

Fraser, P., Pruzina, S., Antoniou, M. and Grosveld, F. (1993). Each hypersensitive site of the human beta-globin locus control region confers a different developmental pattern of expression on the globin genes. Genes Dev. 7, 106-13.

Grosveld, F., van Assendelft, G. B., Greaves, D. R. and Kollias, G. (1987). Position-independent, high-level expression of the human beta-globin gene in transgenic mice. Cell 51, 975-85.

Guy, L.-G., Kothary, R., DeRepentigny, Y., Delvoye, N., Ellis, J. and Wall, L. (1996). The beta-globin locus control region enhances transcription but does not confer position-independent expression onto the lac $Z$ gene in transgenic mice. EMBO J. 15, 3713-3721.

Hardison, R., Xu, J., Jackson, J., Mansberger, J., Selifonova, O., Grotch, B., Biesecker, J., Petrykowska, H. and Miller, W. (1993). Comparative analysis of the locus control region of the rabbit beta-like gene cluster: HS3 increases transient expression of an embryonic epsilon-globin gene. Nucleic Acids Res. 21, 1265-72.

Hebbes, T. R., Thorne, A. W., Clayton, A. L. and Crane-Robinson, C. (1992). Histone acetylation and globin gene switching. Nucleic Acids Res. 20, $1017-22$.

Hug, B. A., Wesselschmidt, R. L., Fiering, S., Bender, M. A., Epner, E., Groudine, M. and Ley, T. J. (1996). Analysis of mice containing a targeted deletion of beta- globin locus control region $5^{\prime}$ hypersensitive site 3. Mol. Cell. Biol. 16, 2906-2912.

Jimenez, G., Gale, K. B. and Enver, T. (1992a). The mouse beta-globin locus control region: hypersensitive sites 3 and 4. Nucleic Acids Res. 20, 5797-803.

Jimenez, G., Griffiths, S. D., Ford, A. M., Greaves, M. F. and Enver, T. (1992b). Activation of the beta-globin locus control region precedes commitment to the erythroid lineage. Proc. Natl Acad. Sci. USA 89, 10618-22.

Kim, C. G., Epner, E. M., Forrester, W. C. and Groudine, M. (1992). Inactivation of the human beta-globin gene by targeted insertion into the beta-globin locus control region. Genes Dev. 6, 928-38.

Kioussis, D., Vanin, E., deLange, T., Flavell, R. A. and Grosveld, F. G. (1983). Beta-globin gene inactivation by DNA translocation in gamma betathalassaemia. Nature 306, 662-6.

Kollias, G., Wrighton, N., Hurst, J. and Grosveld, F. (1986). Regulated expression of human A gamma-, beta- and hybrid gamma beta-globin genes in transgenic mice: manipulation of the developmental expression patterns. Cell 46, 89-94.

Kothary, R., Clapoff, S., Brown, A., Campbell, R., Peterson, A. and Rossant, J. (1988). A transgene containing lacZ inserted into the dystonia locus is expressed in neural tube. Nature 335, 435-7.

Kothary, R., Clapoff, S., Darling, S., Perry, M. D., Moran, L. A. and Rossant, J. (1989). Inducible expression of an hsp68-lacZ hybrid gene in transgenic mice. Development 105, 707-14.

Kothary, R., Perry, M. D., Moran, L. A. and Rossant, J. (1987). Celllineage-specific expression of the mouse hsp68 gene during embryogenesis. Dev. Biol. 121, 342-8.

Lowrey, C. H., Bodine, D. M. and Nienhuis, A. W. (1992). Mechanism of DNase I hypersensitive site formation within the human globin locus control region. Proc. Natl Acad. Sci. USA 89, 1143-7.

Milot, E., Strouboulis, J., Trimborn, T., Wijgerde, M., De Boer, E., Langeveld, A., Tan-Un, K., Vergeer, W., Yannoutsos, N., Grosveld, F. and Fraser, P. (1996). Heterochromatin effect on the frequency and duration of LCR mediated gene transcription. Cell, in press.
Moon, A. M. and Ley, T. J. (1991). Functional properties of the beta-globin locus control region in K562 erythroleukemia cells. Blood 77, 2272-84.

Nandi, A. K., Roginski, R. S., Gregg, R. G., Smithies, O. and Skoultchi, A. I. (1988). Regulated expression of genes inserted at the human chromosomal beta-globin locus by homologous recombination. Proc. Natl Acad. Sci. USA $\mathbf{8 5}, 3845-9$.

Patterton, D. and Wolffe, A. P. (1996). Developmental roles for chromatin and chromosomal structure. Dev. Biol. 173, 2-13.

Pawlik, K. M. and Townes, T. M. (1995). Autonomous, erythroid-specific DNase I hypersensitive site formed by human beta-globin locus control region (LCR) 5' HS 2 in transgenic mice. Dev. Biol. 169, 728-32.

Philipsen, S., Pruzina, S. and Grosveld, F. (1993). The minimal requirements for activity in transgenic mice of hypersensitive site 3 of the beta globin locus control region. EMBO J. 12, 1077-85.

Philipsen, S., Talbot, D., Fraser, P. and Grosveld, F. (1990). The beta-globin dominant control region: hypersensitive site 2. EMBO J. 9, 2159-67.

Pruzina, S., Antoniou, M., Hurst, J., Grosveld, F. and Philipsen, S. (1994) Transcriptional activation by hypersensitive site three of the human betaglobin locus control region in murine erythroleukemia cells. Biochim. Biophys. Acta 9, 351-60.

Pruzina, S., Hanscombe, O., Whyatt, D., Grosveld, F. and Philipsen, S. (1991). Hypersensitive site 4 of the human beta globin locus control region. Nucleic Acids Res. 19, 1413-9.

Raap, A. K., van de Corput, M. P., Vervenne, R. A., van Gijlswijk, R. P., Tanke, H. J. and Wiegant, J. (1995). Ultra-sensitive FISH using peroxidase-mediated deposition of biotin- or fluorochrome tyramides. Hum. Mol. Genet. 4, 529-34.

Reitman, M., Lee, E., Westphal, H. and Felsenfeld, G. (1993). An enhancer/locus control region is not sufficient to open chromatin. Mol. Cell Biol. 13, 3990-8.

Robertson, G., Garrick, D., Wu, W., Kearns, M., Martin, D. and Whitelaw, E. (1995). Position-dependent variegation of globin transgene expression in mice. Proc. Natl Acad. Sci. USA 92, 5371-5.

Russell, E. S. and Bernstein, S. E. (1966). Blood and blood formation. In Biology of the Laboratory Mouse, Second Edition (ed. E.L. Green), pp. 351372. New York, McGraw-Hill.

Ryan, T. M., Behringer, R. R., Martin, N. C., Townes, T. M., Palmiter, R. D. and Brinster, R. L. (1989). A single erythroid-specific DNase I superhypersensitive site activates high levels of human beta-globin gene expression in transgenic mice. Genes Dev. 3, 314-23.

Shehee, W. R., Loeb, D. D., Adey, N. B., Burton, F. H., Casavant, N. C., Cole, P., Davies, C. J., McGraw, R. A., Schichman, S. A., Severynse, D. M., Voliva, C. F., Weyter, F. W., Wisely, G. B., Edgell, M. H. and Hutchison, C. A. III (1989). Nucleotide sequence of the BALB/c mouse beta-globin complex. J. Mol. Biol. 205, 41-62.

Shehee, W. R., Oliver, P. and Smithies, O. (1993). Lethal thalassemia after insertional disruption of the mouse major adult beta-globin gene. Proc. Natl Acad. Sci. USA 90, 3177-81.

Shivdasani, R. A. and Orkin, S. H. (1996). The transcriptional control of hematopoiesis. Blood 87, 4025-4039.

Stamatoyannopoulos, J. A., Goodwin, A., Joyce, T. and Lowrey, C. H. (1995). NF-E2 and GATA binding motifs are required for the formation of DNase I hypersensitive site 4 of the human beta-globin locus control region. EMBO J. 14, 106-16.

Talbot, D., Collis, P., Antoniou, M., Vidal, M., Grosveld, F. and Greaves, D. R. (1989). A dominant control region from the human beta-globin locus conferring integration site-independent gene expression. Nature 338, 352-5.

Talbot, D., Philipsen, S., Fraser, P. and Grosveld, F. (1990). Detailed analysis of the site 3 region of the human beta-globin dominant control region. EMBO J. 9, 2169-77.

Taramelli, R., Kioussis, D., Vanin, E., Bartram, K., Groffen, J., Hurst, J. and Grosveld, F. G. (1986). Gamma delta beta-thalassaemias 1 and 2 are the result of a $100 \mathrm{kbp}$ deletion in the human beta-globin cluster. Nucleic Acids Res. 14, 7017-29.

Tuan, D., Solomon, W., Li, Q. and London, I. M. (1985). The 'beta-likeglobin' gene domain in human erythroid cells. Proc. Natl Acad. Sci. USA 82 , 6384-8.

Tuan, D. Y., Solomon, W. B., London, I. M. and Lee, D. P. (1989). An erythroid-specific, developmental-stage-independent enhancer far upstream of the human 'beta-like globin' genes. Proc. Natl Acad. Sci. USA 86, 2554-8.

Wijgerde, M., Grosveld, F. and Fraser, P. (1995). Transcription complex stability and chromatin dynamics in vivo. Nature 377, 209-13.

(Accepted 10 September 1996) 